\title{
The Benefits and Burden of Joint audits: Do they improve Audit Quality?
}

\author{
Dr Mohamed Hegazy - \\ American University in Cairo \\ Dr Hekmat Ibrahim - \\ Ain Shams University, Egypt
}

\begin{abstract}
Purpose: This paper investigates and assesses whether a joint audit engagement results in high audit quality compared to a single audit given the various characteristics of the audit firm as well as the complexity of the clients' activities.

Design/methodology/approach: The research adopts a survey-based questionnaire sent to external auditors of five audit firms with international affiliation including two of the Big 4 to assess their perceptions about whether joint audit enhances audit quality compared to a single audit. Also, interviews with professionals and academics in the auditing field were made to get their opinions concerning joint versus single audits. Descriptive and Inferential statistics and nonparametric tests were used to test the research's hypotheses.
\end{abstract}

Findings The results reveal that joint audit does enhance the quality of the audit as joint auditors are alert to deliver audit quality and ensure continuity with the client. The results also confirm the importance and necessity to perform joint audit engagements involving one of the Big 4 with one audit partner possessing industry specialization related to the audit engagement. However, no variation was found in audit quality in a joint audit compared with a single audit for listed companies compared with non-listed companies even when there are discrepancies in the joint audit partners' level of competence and experience relevant to the audit engagements.

Originality/value - This study is among the first that survey the impact of joint audit compared to single audit on audit quality in an emerging economy. The study also identifies valuable insights for those two types of the audit with recommendations for the use of joint audit for business enterprises to enhance audit quality.

Limitations The research study relied on a sample of auditors and audit firms for investigating the effect of joint/single audits on audit quality.

Keywords Joint audit, Single audit, Big 4, Industry specialization, Audit tenure, Egypt. 


\section{1- Introduction:}

Recent financial and business scandals have raised concerns regarding the independence of external auditors and the quality of the audit they provide (Lobo et al., 2013). Such issues have led regulators and other stakeholders to call for more regulations and governance to improve auditor independence, with the goal of restoring trust in the quality of financial reporting. The European Commission (EC, 2010) responded to the alleged lack of market trust in auditor independence by issuing a green paper aimed at stimulating discussions on how to improve audit regulation to enhance audit quality and audit market competition. The Green Paper proposed several mechanisms to improve both the ability of the auditor to detect material misstatements and to create incentives to report these detected misstatements. These mechanisms were related to the concepts of joint audits, auditor(s) rotation, audit committees, and restrictions on the provision of non-audit services (EC 2010).

Despite the conventional wisdom that "Two heads are better than one" (Francis and Yu, 2009) or as the EC (2010) noted "Four eyes are better than two", the need for joint audit has led to substantial debate on whether it compromises the quality of the audit provided (Deng et al, 2014). Some researchers claimed that the main advantage of joint audit is the reduction in the market concentration currently presented by hiring only the Big four (Velte and Azibi, 2015). In Europe, France (Ratzinger-Sakel et al., 2012; Audousset-Coulier., 2012) currently requires mandatory joint audits and Denmark also did so since 1930 (Holm and Thinggaard, 2012). Similarly, South Africa also mandated joint audit in the financial services sector (Deng et al, 2014). Other countries allowing the practice of joint audit include Algeria, Morocco, Tunisia, India, Saudi Arabia, Kuwait and the United Kingdom; all have proposed voluntary joint audit (Alanezi et al., 2012; Alsadoun and Aljabr, 2014; Ratzinger-Sakel et al., 2012). Since 2011, joint audits were not made obligatory but were encouraged by the EC and the European Parliament.

On the other hand, prior research attempting to compare the effect of joint and single audit on audit quality is limited. Some studies examined the impact of joint audit on audit costs and audit market concentration but did not provide direct evidence about the benefits or drawbacks of joint versus single audits. For example, Deng et al., (2014) did not discuss the costs and benefits of the joint audit including how it can enhance audit quality due to auditor independence $(E C, 2010)$ and stricter and more relentless audits. The conventional wisdom suggests that it is more expensive for a company to "bribe" and "manipulate" two audit firms than a single firm" (Zerni et al. 2012). Joint audit also may weaken the economic bonding between the auditor and the client because of fee sharing between the auditors (Mazars, 2010). Moreover, joint auditors usually rotate at different times, increasing the auditors' independence while ensuring continuity by preserving the auditors' clients' knowledge (Carcello and Nagy, 2004). Joint audit increases the probability of detecting material misstatements because another auditor reviews the same work of the client. Finally, joint audits benefit from complementarities of expertise and geographical coverage between the two auditors' teams leading to better solutions for problems in which judgment needs 
to be exercised (Mazars, 2010). Egypt is considered one of the few countries where the practice of joint audits was recommended and, in some circumstances, made obligatory by laws and regulations even before the release of the Green paper by the EC. The Central Bank of Egypt (CBE) issued law no.88/2003, stating that banks must have at least two independent auditors to undertake the audit of the banks. Moreover, the Government auditor is appointed the auditor of any company that has $20 \%$ or more state ownership in addition to having another auditor appointed by its shareholders. Thus, many companies in Egypt whether listed or unlisted have joint audit.

Based on the above literature discussions, the current study investigates the association between joint/single audits and audit quality taking into consideration some characteristics of the audit firm including the audit partners' competence, years of experience, industry specialization and the qualifications and the experience of the audit teams. The research also analyzed the effects of the types of auditors in joint audit on audit quality. Few research papers in the audit literature differentiated between the effects of Big 4 and non-Big 4 auditors in joint audit engagements (Dopuch and Simunic 1980; De Angelo 1981). The current research extends the literature for joint audit findings related to the characteristics of the audit firm as well as the complexities of the clients. The remainder of this paper is structured as follows. The second section reviews the literature for the single and joint audit concepts showing the benefits associated with each and the developed research hypotheses. The third section discusses the research methodology. The fourth section reviews the results for the data collected. Conclusions, limitations, and recommendations for future research are presented in the last section of the paper.

\section{2- Literature Review and Hypotheses Development:}

\subsection{Joint audit and audit quality}

There is consensus among researchers regarding the definition of the Joint Audit (Zerni et al., 2012, Alanezi et al., 2012, Baldauf and Steckel, 2012, Paugam and Ramond, 2015). Zahra and Josep-Garcia (2019) defined joint audit as an audit associates with audit task accomplished by two independent auditors in which both are responsible for the final report. In joint audits the two audit firms coordinate in audit planning and related efforts, periodic cross reviews, mutual quality controls, signing a single audit report and bearing joint liability in case of audit failure. Few research papers investigated and assessed the effect of joint/single audit on the audit quality. Such prior studies had a mixed results and findings. Some studies focused on whether joint audit improves or impairs audit quality and some found a positive association between them (Francis and Yu., 2009; Marmousez 2009; Holm and Thinggaard, 2010; Lesage et al 2012 and 2017; Alfaraih and Alanezi, 2012; Alanzei et al., 2012; Paugam and Casta, 2012; Chihi and Mhiris, 2013; Alsadoun and Aljabr, 2014; Deng el al, 2014 and Velte and Azibi, 2015). Other researchers found that the relationship between the joint audit and audit quality is contingent on the type of joint audit regime and the mix of joint auditors appointed (Francis and Yu 2009; Marmousez, 2009; Alfaraih and Alanezi, 2012; Lesage et al, 2012; Lobo et al., 2013; and Andrè et al., 2016). In a case study conducted by Baldauf and Steckel (2012), they found that audit reports issued by 
auditors in joint audit are more conservative and more accurate than that issued by a single auditor. Moreover, they found that the communication and discussion of findings between auditors in the joint audit processes enhance the rationalization and accuracy of the audit opinion expressed, thus improving the audit quality. Benali (2013) found a positive significant impact of joint audit on the shareholders' confidence in the financial statements of French listed companies audited by joint auditors.

Similarly, Zerni et al., (2012) in a study for some Swedish companies found that Swedish firms that engaged into voluntary joint audit engagements experienced higher levels of audit quality and conservatism, lower abnormal accruals, higher credit rating, and lower risk of forecasted earnings. Furthermore, using a sample of the largest European listed companies, Relvas and Pais (2015) showed that the cost of debt in the companies audited by two auditors is lowered compared to companies audited by a single auditor. Lesage et al (2017) also discovered that increased monitoring due to voluntary joint audit lead to higher audit quality. Other researchers found similar results of the implications of voluntary joint audit on audit quality (Baldauf and Steckel, 2012; Benali, 2013; Ittonen and Tronnes, 2015; Relvas and Pais, 2015). For example, Ittonen and Tronnes (2015) concluded that joint audit engagements are associated with lower abnormal accruals and timely recognition of economic losses as proxies of audit quality. However, they did not find any association between joint audit and total accruals and the probability of reporting profit. Similarly, Holm and Thinggaard, (2010) and Lesage et al (2012) found no significant difference in the level of abnormal accruals between companies audited by two audit firms compared with companies audited by a single audit firm for a sample of companies listed in the Copenhagen Stock Exchange. They emphasized that single audit is more effective in constraining earnings management than joint audit. Moreover, Velte and Azibi (2015) using a sample of German and French listed companies found that joint audit engagements have no significant impact on the level of abnormal accruals or discretionary accruals in both countries. At the same time, Holm and Thinggaard, (2016) argued that the Big CPA firms are likely to increase their audit fees in joint audit engagements in case of free riding to be compensated for the audit work performed.

On the other hand, opponents of the joint audit (Holm and Thinggaard 2010; Zerni et al., 2012; Deng et al., 2014; and Alsadoun and Aljaber, 2014) argue that the practice of joint audit impairs the audit quality for various reasons. Joint audit could result in an opinion shopping problem, because management may offer to purchase the audit opinion of the small audit firm and the Big audit firm will bear the consequences and reputation cost alone. It could also result in free riding problem because small audit firms have fewer resources than the Big 4 audit firms when the latter perform most of the audit work. Finally, joint audit may lead to insufficient information exchange resulting in compromising audit quality, because auditors from competitive audit firms may not have an incentive while conducting the audit work. Thus, joint audit and its implications on the audit quality is still a debatable issue requiring further research investigations. Accordingly, we 
present our first hypothesis related to the relationship between single and joint audit and audit quality as follows:

\section{H1: There are no differences in the quality of the audit between joint and single audit engagements.}

\subsection{Joint Audit and the Size of the audit firm}

There is an obvious interrelationship between the audit firm classification (Big or Small) and the level of technology efficiency in such audit firms. Deng et al., (2014) and Holm and Thinggaard (2016) presumed that all small audit firms have comparable or lower technology efficiency relative to the Big audit firms. Similarly, Philippe and Simunic (2011) examined the relationship between the audit quality and the audit firm size, the structure of the audit firm, and the market concentration in the audit industry. They concluded that a non-Big audit firm cannot replicate an audit conducted by a Big 4 as the later control larger market shares and they retain superior audit technologies, which allow them to perform audit with high quality at relatively lower costs. In addition, other researchers (Marmousez, 2009; Francis and Yu, 2009; Paugam and Casta 2012; Alfaraih and Alanzei 2012; Audousset-Coulier, 2012; Chihi and Mhirsi 2013; Alsadoun and Aljaber 2014; Lobo et al., 2017 and Beck et al., 2019) found that companies audited by two Big 4 audit firms tend to have lower abnormal accruals. Similar results were found by Francis and Yu (2009) who indicated that companies with less ownership structure concentration and lower rates of family ownership are more likely to appoint at least one Big 4 audit firm. Francis and Michas (2013) found evidence that Big 4 audit firms deliver higher audit quality than smaller offices. Big 4 audit firms operate in a decentralized organization structure, which enables their personnel develop better knowledge of existing and potential clients in a location where the client belongs (Ferguson et al., 2003). Clients in turn earn more confidence in the expertise of the locally based audit firms whose personnel have more "in-house" experience to perform the audit work (Hermanson et al, 1992). Thus, audit firm size is viewed as a proxy for the audit quality because lower economic reliance on any single client makes larger audit firms less likely to behave opportunistically to retain their client. Also, large CPA firms are more motivated on preserving and maintaining their good reputation (Khurana and Ruman 2004; Behn, et al., 2008 and Lobo et al, 2017). Given the above arguments, the following research hypothesis is developed:

\section{H2: There are no differences in the quality of the audit between joint and single audit that involves one or more of the Big 4 audit firms.}

\subsection{Joint audit and Partners level of competence and experience}

Effective and efficient Joint audit could affect two components of audit quality (i.e., independence and competence). The advantages of joint auditors' competence lie in the concept that four eyes are expected to have more detecting ability than two eyes. Also, auditors in joint audit will seek to dominate each other to protect their reputation and during auditors' rotations, the remained auditors will retain the acquired knowledge and expertise in the company (Carcello et al., 1992 
and Al-Khaddash et al., 2013). On the other hand, some of the disadvantages of joint audit's competence are when two auditors co-audit several companies, their extensive knowledge of each other may result in cross review procedures, reducing their surveillance of the work. Also, auditors can prevent the exchange of adequate information with their co-auditor to retain their competitive capability (Zahra and Josep-Garcia, 2019). Some research studies have found a positive association between audit quality and auditors' qualifications, proficiency, and technical capabilities. Also, the level of education, professional experience, and certifications held by the auditors are found to be associated with the auditor's remuneration and the hourly fees rate (Beck et al, 2019). Moreover, Deng et al., (2014) indicated that the Big 4 audit firms have an advantage over the smaller audit firms in terms of technology and expertise used in the audit work. Big 4 audit firms invest more resources in information technology and software, and they have manuals and quality control standards, continuous educations and training for its employees and in-house specialists to consult with during the audit process leading to more cost-effective audit. Deng et al., (2014) suggested that when pairing and practicing joint audit, the differences in technological efficiencies should be considered when assessing the audit quality and comparing it to the single audit engagements. The model BB (Joint audit by two Big firms) predicts that joint audit, where the two audit firms have comparable technological efficiencies and they provide the same audit quality as a single audit, will enhance the overall audit quality, whereas pairing with a firm with lower technological efficiencies (BS model - one small and one Big audit firm) will reduce the overall audit quality. Similar results were found in Holm and Thinggaard (2018) study.

On the other hand, Lesage et al. (2017) found no differences in audit quality between companies that employ one or two audit firms. However, the indicator used in this study for assessing the effect of involving a Big 4 audit firms did not distinguish between joint audit and single audit engagements. Similarly, Andre' et al., (2016) found no differences in audit quality measured by different proxies for earnings management between French companies with joint audit with either two Big or one Big audit firm and UK or Italian companies audited by a single Big audit firm. Thus, it is also possible that the competence of a single Big 4 auditor is enough to ensure the requisite level of audit quality, and thus the difference in competence may not manifest in different audit quality. So, the third hypothesis is formulated as follows:

\section{H3: There are no differences in the quality of the audit between joint and single audit where partners have different levels of experience, competence, and qualifications}

\subsection{Joint audit and client's complexity}

We classify complex audit engagement (client's complexity) based on the nature of the client's structure, size, geographical dispersion, locally and internationally client's subsidiaries (Hossain et al, 2017). Prior studies have investigated some indicators of the client's size including client's market value, number of employees and sales. However, most researchers favored the value of total assets as the most used indicator of the client's size (Abdel Razik, 2017). Arens et al., (2013) concluded that the problem with client complexity is that it cannot be observed directly. For 
example, Hay et al., (2006) found that the measurement of the client complexity varies among studies. There are two main streams in the literature. Some researchers assumed that the client company structure can cause the complexity. They used the number of subsidiaries that a firm locally and internationally owns as a proxy to represent it; a company with more subsidiaries has decentralized operations and consequently are more complex concerning the audit. Other researchers assumed that complexity can be categorized as industry characteristics, which imply that some industries are more complex to the audit than others using the Standard Industrial Classification (SIC) codes (Bills et al., 2013). Moreover, Ittonen and Tronnes (2015) used alternative proxy for audit quality, where the benefits of the joint engagement partners and the location of those partners differed for client audits with higher and lower level of complexity. They used a composite measure of client's audit complexity, which is a function of client size, industry, geographical dispersion at both the national level and the international level, and the client subsidiary complexity. The national and international geographical dispersion complexity were assessed based on the number of different cities within the country and outside it in which the firm had its headquarters and in which the firm had its registered subsidiaries. They also measured subsidiary complexity as the number and the nature of the different subsidiaries. No research study did assess the client's complexities using the notion of listed versus non-listed companies. Thus, the following research hypothesis is formulated:

\section{H4: There are no differences in the quality of the audit between joint and single audit for the client's complexity.}

\section{3- Data collection and Analysis}

The population of this research includes partners, managers, vice managers, senior auditors, and auditors in 5 audit firms with international affiliation including two of the Big 4 audit firms. A series of interviews were conducted with five partners and ten audit managers of the five selected audit firms for data collection and analysis as well as two professors of auditing to assess the prototype questionnaire developed by the researchers based on the review of the literature. The closed ended questionnaire, using a five-point Likert scale with the numbers from 1 to 5 , consists of five sections, each section contains the data related to testing one of the five research hypotheses (Saunders et al., 2007). Two hundred and fifty questionnaires were sent during the second half of 2018 to the five audit firms (fifty questionnaires to each audit firm) for distribution within their various audit management levels. 172 questionnaires were returned with responses. Table 1 summarizes the response rate among participants. 
Table 1: Summary of the response rate of participants

\begin{tabular}{|l|c|}
\hline & Auditors \\
\hline Questionnaires mailed & 250 \\
\hline No. of responses & 176 \\
\hline Unreturned questionnaires & 74 \\
\hline Response rate & 0.70 \\
\hline
\end{tabular}

\section{3-1 Demographic profile of the respondents}

The demographic data includes gender, years of experience and jobs as shown in table 2. For the gender, most of the sample were males with $76.2 \%$, while females represented $23.8 \%$. More than one third of the sample (i.e. 33.7\%) had experience from one year to less than three years, $31.4 \%$ had three to less than five years of experience, while $23.3 \%$ had experience more than ten years. Senior auditors and auditors represented $35.4 \%$, and $29.1 \%$ of the sample, respectively. Audit managers and vice managers represented $16.9 \%$, and $16.3 \%$ respectively.

Table 2: Summary of the demographic data of the sample respondents

\begin{tabular}{|l|c|c|}
\hline Gender & \multicolumn{1}{l|}{ Frequency } & Percent \\
\hline Male & 131 & 74.4 \\
\hline Female & 45 & 25.6 \\
\hline Years of experience & 60 & 34.1 \\
\hline $1-3$ years & 56 & 31.8 \\
\hline $3-5$ years & 20 & 11.4 \\
\hline $5-10$ years & 40 & 22.7 \\
\hline$>10$ years & \multicolumn{2}{l|}{} \\
\hline Job & 7 & 4.0 \\
\hline Partners & 29 & 16.5 \\
\hline Audit Managers & 28 & 15.9 \\
\hline Vice audit managers & 60 & 34.1 \\
\hline Senior auditors & 52 & 29.5 \\
\hline Auditors & 176 & 100 \\
\hline Total & \multicolumn{2}{|l}{} \\
\hline
\end{tabular}




\subsection{Testing the reliability of the questionnaire:}

Cronbach's Alpha tested the reliability of the questionnaire and the respondents' answers (Saunders et al 2007). The value of Alfa ranges from $77.8 \%$ to $89.2 \%$ concerning the sections of the questionnaire, and it reaches 0.928 for the whole questionnaire. Since the value exceed $70 \%$, the questionnaire is reliable, and we can depend on the results obtained from it.

\section{4- Results and Discussion}

\subsection{Descriptive and Inferential statistical Tests for $\mathrm{H1}$}

To test hypothesis 1 , we divided the questions of section one into two parts. Part 1 includes questions concerning the joint audit engagement; q1, q2, q3, q4, q9, q10, q11, q14, q15, q16, q17. Part 2 includes questions concerning single audit engagement; q5, q6, q7, q8, q12, q13. Table 3 shows that most of the auditors surveyed agree that the joint audit outweighs the single audit in relation to achieving audit quality because of the following elements. First, joint audit helps to keep the audit firms on their toes to ensure that each firm delivers high audit quality and ensure continuity with the client with mean value of 4.19 (EC, 2010). Second, joint audit benefits from brainstorming among the auditors involved in the audit work (mean value of 4.12), a matter which helps identify possible misstatements in the financial statements. This is consistent with the findings of Zerni et al, (2012) who stated that joint audit will make it more difficult for management to manipulate financial statements. Moreover, if the audited client has complex transactions (i.e. degree of difficulty of the audit), the joint audit firms achieve a high level of interconnectedness in the performance of the audit (EC, 2010 and Francis and Yu, 2009).

Third, the intense competition between the two joint auditors fulfilling the same audit work affect positively audit quality (mean value of 3.91) given that the collusion between management and the audit firms become more difficult. This is consistent with the findings in Mazars (2010), Zerni et al (2012) and Alsadoun and Aljabr (2014). Fourth, joint audit helps to mitigate the risk of over familiarity with the client (mean value of 3.90) as the work among the joint auditors can always be rotated resulting in a positive effect on the independence of the joint auditors (Similar results were found in the studies of Carcello and Nagy, 2004, Lobo et al, 2013 and Deng et al, 2014). Fifth, because of multiple contacts with the auditee by more than one audit firm; the number of audited issues that one audit firm may not be able to uncover increases with a mean value of 3.85 . Finally, joint audit enhances audit quality as the two audit firms may have previously worked together or worked together on the same audit engagement in the previous period with a mean value of 3.72 (See similar findings in Baldauf and Steckel, 2012 and Relvas and Pais, 2015). Due to the willingness of each participating office to obtain a business opportunity (provision of consulting work/ non-audit services), joint audit allows cross review of each of the joint auditors' work with mean value of 3.48. Based on the above discussion of joint audit factors, we conclude that the respondents supported the joint audit engagement with an overall mean of 3.87. Such results are consistent with one partner's opinion who indicated that: "Whenever I am responsible for a joint audit, I feel slightly pressured as I raise my concentration to ensure that my firm 
outweighs the quality standards of the other audit firm". Another partner provided a surprise quotation by indicating: "whenever I am called for a joint audit, I first ask about the partner responsible from the other office and if he has a good reputation for quality then I really enjoy the audit and I feel confident that cost saving will be achieved due to less efforts and time would be spent in the engagement".

Table 3: Descriptive analysis for questions concerning the joint audit engagement

Variables

X1_01 The joint audit increases the quality of the audit through brainstorming among auditors involved in the performance of the audit work.

X1_02 The joint audit increases the quality of the audit due to intense competition between the joint auditors fulfilling the same audit work. X1_03 The joint audit increases the quality of the audit due to the willingness of each participating audit firm to obtain consulting and non-audit services.

X1_04 The joint audit increases the quality of the audit as it helps to keep the audit firms on their toes to ensure that each firm delivers high audit quality and ensure continuity with the client.

X1_09 The Joint audit increases the quality of the audit as a result of multiple contacts with the auditee -by more than one audit firm; thereby increasing the number of audited issues that one audit firm may not be able to uncover.

X1_10 The joint audit increases the quality of audit as it helps to mitigate risk of over familiarity with the client as the work among the joint auditors can always be rotated.

$\mathrm{X} 1 \_11$ The joint audit increases the quality of the audit as collusion between the management of the client and the audit firms become more difficult.

X1_14 The joint audit increases the quality of the audit as it allows cross review of each of the joint auditors' work

X1_15 The joint audit increases the quality of the audit if the two firms have previously worked together or worked together on the same audit engagement in the previous period.

X1_16 The Joint audit increases the quality of the audit compared to a single audit when the two audit firms have a high level of interconnectedness in the performance of the audit.

X1_17 The joint audit increases the quality of the audit compared to single audit if the audited client has complex transactions (i.e. degree of difficulty of the audit).

X1_A (Overall mean)

\begin{tabular}{|c|c|c|c|c|}
\hline $\begin{array}{l}3 \\
\stackrel{3}{8} \\
\stackrel{\Xi}{0}\end{array}$ & 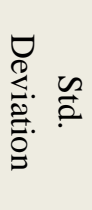 & 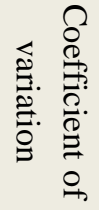 & 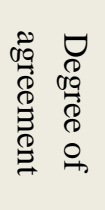 & $\begin{array}{l}\text { D } \\
\text { 关 }\end{array}$ \\
\hline 4.12 & 0.79 & 19.1 & Agree & 2 \\
\hline 3.91 & 0.96 & 24.6 & Agree & 5 \\
\hline 3.58 & 1.11 & 30.9 & Agree & 11 \\
\hline 4.19 & 0.87 & 20.8 & Agree & 1 \\
\hline 3.85 & 0.97 & 25.3 & Agree & 9 \\
\hline 3.90 & 1.04 & 26.6 & Agree & 6 \\
\hline 3.90 & 0.97 & 24.8 & Agree & 7 \\
\hline 3.48 & 1.33 & 38.3 & Agree & 12 \\
\hline 3.72 & 0.89 & 23.8 & Agree & 10 \\
\hline 3.95 & 0.97 & 24.4 & Agree & 3 \\
\hline 3.94 & 0.91 & 23.1 & Agree & 4 \\
\hline 3.87 & 0.58 & 14.9 & Agree & 8 \\
\hline
\end{tabular}


At the same time, one of the Big 4 partners indicated "it does not make any difference whether we are providing a single or joint audit as we are required to apply our audit approach for the client to comply with the requirements of our international network". Another partner from the Big 4 highlighted the problems related with joint audit and raised the alarm that in several engagements, the audit team from the other audit firm relied on the work performed by his firm without undertaking significant audit tests. He indicated "when we sat with the management of the client I found that the partner and audit manager of the other firm did not know anything about a substantial number of customers for the audit of the loan portfolio of such financial institution even though the account balance is considered material in the institution's financial statements".

On the other hand, table 4 shows that auditors were neutral and did not support the view that single audit enhances audit quality compared with joint audit engagement. Auditors confirmed that the joint audit may impair audit quality in case coordination problems occur among joint auditors (see Ittonen and Tronnes, 2015 for similar results). For example, the joint audit may extend the length of the audit period as a result of each audit firm performing its own audit procedures and the quality of the audit work is also impaired or reduced due to overreliance on the counterpart auditor (Holm and Thinggaard, 2010 and Lesage et al, 2012). One partner of the Big 4 indicated "When we are assigned a joint engagement I am always worried about the cost, time and efforts provided in the engagement as the client expect high quality of services because we are two auditors". He added that sometimes the other auditor "act unethically in relation to the engagement by saving cost due to his reliance on our firm and its reputation". Similarly, one partner in nonBig 4 audit firm confirmed the inability of the Big 4 to provide adequate number of staff for the engagement due to cut costs of the audit and the pressure from the provision of the audit to a large number of clients at the same time: "I find myself facing a difficult situation for the performance of the audit due to inability of my joint Big 4 firm to share equally in the audit of the financial statements of the client under audit". However, joint audit may impair the quality of the audit compared to single audit if the audited clients select evidence and rely on the opinion of the auditor who supports their point of view (see Holm and Thinggard, 2010; Deng et al, 2014; Velte and Azibi, 2015 and Zerni et al, 2012 for similar results). In a single audit, the auditor takes full responsibility of the audit work resulting in more effective supervision of the audit team to perform the audit procedures appropriately. 
Table 4: Descriptive analysis for questions concerning a single audit engagement

Variables

$\mathrm{X} 1 \_05$ The quality of the audit is increased in a single audit as there is only one audit firm responsible for performing the audit compared to the joint audit in which more than one audit firms share the responsibility (and related liability) of performing the audit work.

X1_06 The quality of the audit work is impaired or reduced in the joint audit due to overreliance on the counterpart auditor.

X1_07 The joint audit may extend the length of the audit period because of each audit firm performing its own audit procedures.

X1_08 In a single audit, the quality of the audit is increased because there is one auditor responsible for the audit and thus more effective supervision of the audit team to perform the audit procedures appropriately.

$\mathrm{X} 1 \_12$ The joint audit may impair audit quality in case coordination problems occur among joint auditors which may compromise the quality of the audit.

$\mathrm{X} 1 \_13$ The joint audit may impair the quality of the audit if the audited client selects evidence and rely on the opinion of the auditor who supports their point of view.

X1_B (Overall mean)

\begin{tabular}{|c|c|c|c|c|}
\hline $\begin{array}{l}\frac{3}{9} \\
\stackrel{\mathscr{\Xi}}{\Xi}\end{array}$ & 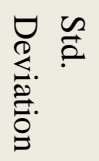 & 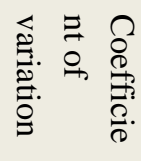 & 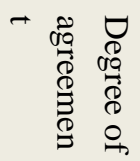 & 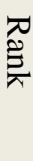 \\
\hline 3.63 & 0.99 & 27.3 & Agree & 2 \\
\hline 2.99 & 1.04 & 34.9 & Neutral & 6 \\
\hline 3.17 & 0.98 & 30.9 & Neutral & 5 \\
\hline 3.62 & 1.02 & 28.1 & Agree & 3 \\
\hline 3.30 & 1.20 & 36.2 & Neutral & 4 \\
\hline 3.65 & 1.05 & 28.6 & Agree & 1 \\
\hline 3.39 & 0.66 & 19.5 & Neutral & \\
\hline
\end{tabular}

\section{Wilcoxon Sign Ranking Test}

We conducted Kolmogorov-Smirnov and Shapiro-Wilk to test the normality of data. The results in the appendix show that the data distribution is not normal (for all hypotheses tested), therefore we will apply Wilcoxson Signed Ranked Test. Table 5 revealed statistically significant differences in the quality of audit work performed in a joint audit compared to single audit engagements $(Z=-$ $4.18, P<0.001)$. Such differences are in favor of joint audit engagements since the median score $(M d=3.86)$ while the median score of single audits is $(M d=3.33)$. Therefore, we accept H1. This is consistent with the results obtained from the descriptive analysis.

Table 5: Wilcoxon signed ranks/sign test between joint and single audit engagement

\begin{tabular}{|l|l|l|c|c|}
\hline \multicolumn{1}{|c|}{ Variables } & \multicolumn{1}{|c|}{ Median } & Z & Sig. & Effect size \\
\cline { 1 - 3 } X1_A The joint audit engagement & 3.86 & & & \\
\cline { 1 - 3 } X1_B The single audit engagement & 3.33 & -8.619 & 0.000 & 0.465 \\
\hline
\end{tabular}




\subsection{Descriptive and Inferential Statistical Tests for $\mathrm{H} 2$}

To test hypothesis 2 , we divided the questions of section two of the survey into two parts. Part 1 includes questions concerning the joint audit engagement; q1, q2, q3, q4, q5, q6, q9. Part 2 includes questions concerning single audit engagement; q7, q8, q10, q11, q12, q13. Table 6 shows that the mean responses of the sample tend to "Strongly agree" that the audit quality is enhanced when the joint audit involves one of the Big 4 audit firms due to the professional qualifications, experience, financial and technical resources available locally and through its network (See Khurana and Ruman, 2004; Behn et al, 2008; Marmousez, 2009; Francis and Yu, 2009; Philippe and Simunic, 2011; Deng et al, 2014; Hegazy et al, 2015; and Holm and Thinggaard, 2016). At the same time, auditors agree with a mean value of 4.19 that the concern of the Big 4 to maintain their reputation worldwide in a joint audit results in the provision of high quality of audit. These results are consistent with the findings obtained by Mazars (2010), Benali (2013), and Velte and Azibi (2015) of the significant impact of the Big 4 on the shareholders' confidence in the financial reports and the benefits of geographical coverage.

Also, some of the partners interviewed other than those at the Big 4 indicated that whenever a Big 4 firm joins in the audit engagement "we feel relaxed concerning the quality of the audit as Big 4 tends to exercise great efforts to show their leadership in the engagement". One partner of an international audit firm showed an exception to such evidence "when the audit is assigned to a branch of the Big 4 in small or distant governorate, the quality of the audit is usually not similar to that undertaken by the Big 4 in the capital or other main governorates. This is due to less resources, technology and competent staff allocated to engagements in such locations". Based on the above results, we can accept H2. Similarly, table 7 also shows that the attitude of the participants tends to "strongly agree" that the quality of the single audit increases if it is carried out by one of the Big 4 audit firms. Such results confirm the importance of the Big 4 in single or joint audit engagements (Deng et al, 2014).

Table 6: Descriptive statistics for audit quality when joint audit involves one of the Big 4 audit firms

\begin{tabular}{|c|c|c|c|c|c|}
\hline & 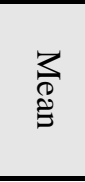 & 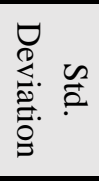 & 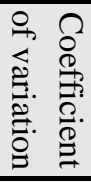 & 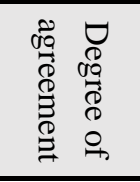 & \\
\hline $\begin{array}{l}\text { X2_01 In general, the quality of the audit increases when the joint audit } \\
\text { involves one of the big four audit firms because of the efficiency and } \\
\text { effectiveness of audit performed by the Big audit firms worldwide. }\end{array}$ & 4.31 & 0.69 & 16.0 & $\begin{array}{l}\text { strongly } \\
\text { agree }\end{array}$ & 1 \\
\hline $\begin{array}{l}\mathrm{X} 2 \text {-02 The quality of the audit increases in a joint audit involving one of } \\
\text { the big four as they are more concerned to maintain their reputation } \\
\text { worldwide and thus deliver audit service with high quality. }\end{array}$ & 4.19 & 0.87 & 20.8 & Agree & 5 \\
\hline $\begin{array}{l}\text { X2_03 The Joint audit involving one of the big four increases the quality } \\
\text { of the audit since the Big } 4 \text { team members possess high levels of } \\
\text { experience and professional qualifications that are not available to other } \\
\text { audit firms. }\end{array}$ & 4.30 & 0.78 & 18.2 & $\begin{array}{l}\text { strongly } \\
\text { agree }\end{array}$ & 3 \\
\hline
\end{tabular}




\begin{tabular}{|l|c|c|c|c|c|}
\hline $\begin{array}{l}\text { X2_04 The quality of the joint audit involving one of the big 4 is increased } \\
\text { due to the availability of resources needed to increase the size, scope, and } \\
\text { the extent of the required audit tests. }\end{array}$ & 4.31 & 0.77 & 17.8 & $\begin{array}{c}\text { strongly } \\
\text { agree }\end{array}$ & 2 \\
\hline $\begin{array}{l}\text { X2_05 The joint audit involving one of the big 4 increases the quality of } \\
\text { the audit due to the technical support provided by their international } \\
\text { networks worldwide. }\end{array}$ & 4.26 & 0.87 & 20.4 & $\begin{array}{c}\text { strongly } \\
\text { agree }\end{array}$ & 4 \\
\hline $\begin{array}{l}\text { X2_06 The joint audit involving one of the big 4 may increase the quality } \\
\text { of the audit compared with a single audit as they will minimize differing } \\
\text { views or interpretations on any key audit matter or a critical accounting } \\
\text { issue }\end{array}$ & 3.84 & 0.93 & 24.2 & Agree & 7 \\
\hline $\begin{array}{l}\text { X2_9 The quality of the audit increases in the joint audit involving two of } \\
\text { the big 4 due to the availability of extensive expertise and qualification } \\
\text { levels for their staff. }\end{array}$ & 3.88 & 0.87 & 22.4 & Agree & 6 \\
\hline X2 A (Overall mean) & 4.16 & 0.58 & 14.0 & Agree & \\
\hline
\end{tabular}

Table7: Descriptive analysis for audit quality when single audit is conducted by one of the Big 4 .

\begin{tabular}{|c|c|c|c|c|c|}
\hline 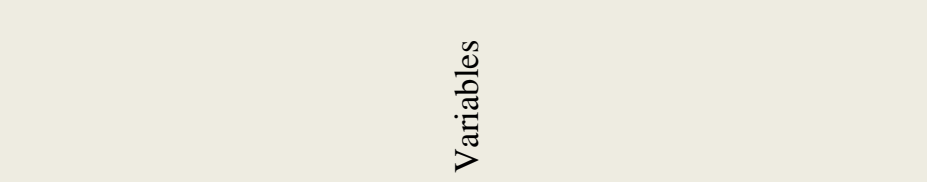 & $\stackrel{\varpi}{\Sigma}^{\stackrel{\varpi}{\Sigma}}$ & 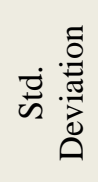 & 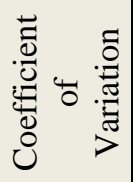 & 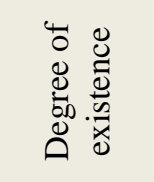 & 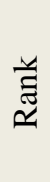 \\
\hline $\begin{array}{l}\text { X2_07 The quality of the single audit increases when the audit is } \\
\text { conducted by one of the big } 4 \text { due to the efficiency and } \\
\text { effectiveness of the audit work carried out by the big } 4 \text { audit } \\
\text { firms worldwide. }\end{array}$ & 3.56 & 0.89 & 24.9 & $\begin{array}{l}\text { Strongly } \\
\text { agree }\end{array}$ & 4 \\
\hline $\begin{array}{l}\text { X2_08 The quality of the single audit increases if the audit is } \\
\text { conducted by one of the big } 4 \text { who is required to maintain its } \\
\text { good reputation. }\end{array}$ & 3.83 & 0.85 & 22.1 & $\begin{array}{l}\text { Strongly } \\
\text { agree }\end{array}$ & 3 \\
\hline $\begin{array}{l}\text { X2_10 The quality of the single audit increases if the audit is } \\
\text { carried out by one of the big } 4 \text { because of the availability of } \\
\text { extensive expertise and qualification levels for its employees. }\end{array}$ & 3.85 & 0.91 & 23.7 & $\begin{array}{l}\text { Strongly } \\
\text { agree }\end{array}$ & 2 \\
\hline $\begin{array}{l}\mathrm{X} 2 \text { 11 The quality of the single audit increases if the audit is } \\
\text { carried out one of the big } 4 \text { due to the availability and sufficiency } \\
\text { of the resources needed to help the firm increases the volume, } \\
\text { scope and extent of the required audit tests. }\end{array}$ & 3.86 & 0.88 & 22.8 & $\begin{array}{l}\text { Strongly } \\
\text { agree }\end{array}$ & 1 \\
\hline $\begin{array}{l}\text { X2_12 The quality of the single audit increases if the audit is } \\
\text { conducted by one of the big } 4 \text { as a result of the optimal use of the } \\
\text { resources of the audit office, and the effort and time in the } \\
\text { implementation of the assignment. }\end{array}$ & 3.37 & 0.94 & 27.8 & Agree & 6 \\
\hline $\begin{array}{l}\text { X2_13 The quality of the single audit increases if the audit is } \\
\text { conducted by one of the big } 4 \text { because there is a good assessment } \\
\text { of the elements that should be disclosed as Key Audit Matters. }\end{array}$ & 3.56 & 0.89 & 24.9 & $\begin{array}{l}\text { Strongly } \\
\text { agree }\end{array}$ & 5 \\
\hline X2_B (Overall mean) & 3.67 & 0.71 & 19.3 & $\begin{array}{l}\text { Strongly } \\
\text { agree }\end{array}$ & \\
\hline
\end{tabular}




\section{Wilcoxon Signed Rank Test}

Table 8 reveals statistically significant differences between the quality of the audit in a joint audit with one of the Big 4 audit firms compared to single audit engagements $(z=-9.93, p<.001)$ with a large effect size $(r=.54)$. Such differences are in favor of joint audit engagements with one of the Big 4 audit firms since the median score is $M d=3.86$ while the median score of single audits with one of the Big 4 is $M d=3.17$. Therefore, we accept $\mathrm{H} 2$.

Table 8: Wilcoxon signed ranks test of audit quality when the joint and single audit involves one of the big four audit firms

\begin{tabular}{|c|c|c|c|c|}
\hline Variables & Median & Z & Sig. & Effect size \\
\hline X2_A Joint audit involving one of the Big 4 audit firms & 3.86 & \multirow{2}{*}{-9.926} & \multirow{2}{*}{0.000} & 0.535 \\
\cline { 1 - 2 } X2_B Single audit with one of the Big 4 audit firms & 3.17 & & \\
\hline
\end{tabular}

\subsection{Descriptive and Inferential Statistical Tests for $\mathbf{H 3}$}

To test hypothesis 3, we divided the questions of section three of the survey into two parts. Part 1 includes questions concerning the joint audit engagement; q1, q2, q3, q4, q5, q6. Q7. Part 2 includes questions concerning single audit engagement; q8, q10, q11, q12, q13, q14. Table 9 shows that auditors tend to "Strongly agree" that the quality of the joint audit increases even if there are differences in the level of experience of the partners responsible for carrying out the audit work (mean=3.88, SD=0.87). Moreover, the attitude of the auditors tends to "agree" that the quality of the joint audit increases even if there are differences in the size of the audit clients, the qualifications, competence, industry specialization and the number of years of experience of the audit team when carrying out the audit work (mean from 3.88 to 2.88). These results are consistent with the findings of other research studies indicating a positive effect on audit quality when audit firms have audit technology efficiency (Holm et al, 2018), and competence of the audit staff whether in small or Big 4 audit firms (Deng et al, 2014 and Lesage et al, 2017). Based on the above results, we accept $\mathrm{H} 3$. However, one audit manager of international audit firm other than the Big 4 complained from the pressure of having to work with the managers and partners of the Big 4 in a joint audit "Whenever I participate in a joint audit with one of the Big 4 especially in financial institutions and insurance companies I carefully read the recent requirements of both IFRS and ISA for such audit engagement so that I can make strong discussions with the manager and partner of the Big 4, thus maintaining my professional respect in front of the client". Another partner in one of the Big 4 audit firm "whenever we are providing our services in a joint audit with smaller audit firm we extent the scope of our audit tests to compensate for any lack of qualifications, experience and industry specialization of the partner and manager of the other audit firm to safeguard the quality of our audit and maintain our international network reputation". 
Table 9: Descriptive analysis of audit quality with differences in level of competence in joint audit.

\begin{tabular}{|c|c|c|c|c|c|}
\hline$\frac{\frac{2}{\pi}}{\stackrel{\frac{\pi}{3}}{\frac{\pi}{\pi}}}$ & $\sum^{\Xi}$ & 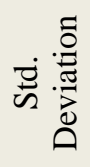 & 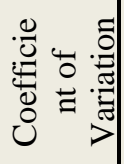 & 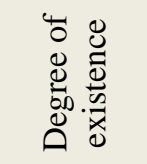 & 光 \\
\hline $\begin{array}{l}\text { X3_01 The quality of the joint audit increases even if there is a } \\
\text { disparity in the level of qualifications of the partners responsible } \\
\text { for carrying out the audit work. }\end{array}$ & 3.35 & 0.71 & 21.1 & Agree & 3 \\
\hline $\begin{array}{l}\text { X3_02 The quality of the joint audit increases even if there is a } \\
\text { disparity in the level of experience of the partners responsible for } \\
\text { carrying out the audit work. }\end{array}$ & 3.88 & 0.87 & 22.4 & $\begin{array}{l}\text { Strongly } \\
\text { agree }\end{array}$ & 1 \\
\hline $\begin{array}{l}\text { X3_03 The quality of the joint audit increases even if there is a } \\
\text { disparity in the level of competence of the partners responsible for } \\
\text { carrying out the audit work. }\end{array}$ & 3.35 & 0.72 & 21.6 & Agree & 4 \\
\hline $\begin{array}{l}\text { X3_04 The quality of the joint audit increases even if there is a } \\
\text { discrepancy in the number of years of the partners responsible for } \\
\text { carrying out the audit work. }\end{array}$ & 3.37 & 0.71 & 21.0 & Agree & 2 \\
\hline $\begin{array}{l}\text { X3_05 The quality of the joint audit increases even if there is a } \\
\text { discrepancy in the size of the clients being audited. }\end{array}$ & 3.32 & 0.78 & 23.4 & Agree & 5 \\
\hline $\begin{array}{l}\text { X3_06 The quality of the joint audit increases in the event of a } \\
\text { disparity in the level of competence, experience and qualifications } \\
\text { of the managers and members of the audit teams given similar } \\
\text { experience and qualifications of the partners responsible for the } \\
\text { engagements }\end{array}$ & 2.88 & 0.83 & 28.8 & Agree & 7 \\
\hline $\begin{array}{l}\text { X3_07 The quality of the joint audit increases if there is a } \\
\text { discrepancy between the audit firms in relation to the industry } \\
\text { experience of the clients under audit. }\end{array}$ & 2.98 & 0.73 & 24.6 & Agree & 6 \\
\hline X3_A (Overall mean) & 3.31 & 0.51 & 15.4 & Agree & \\
\hline
\end{tabular}

In addition, table 10 shows that auditors agree that the quality of the audit increases when it is performed by a single qualified and experienced audit firm represented in the partner(s) in charge and the audit team (mean=2.98, $\mathrm{SD}=0.79$ ). The results also confirm that auditors agree that the quality of the single audit increases if the partner in charge of the engagement has many audited clients and the firm has industry specialization related to the audit clients.

Table 10: Descriptive analysis for the audit with a single competent audit firm.

\begin{tabular}{|c|c|c|c|c|c|}
\hline 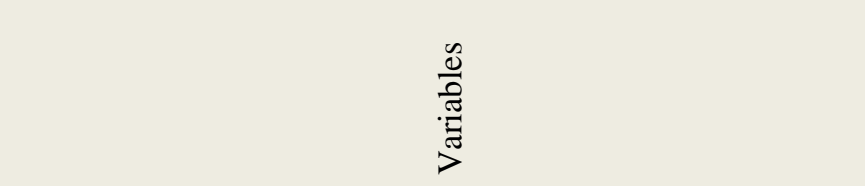 & 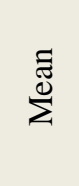 & 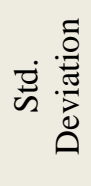 & 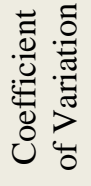 & 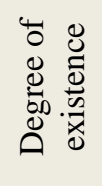 & 䒕 \\
\hline $\begin{array}{l}\text { X3_08 The quality of the single audit increases if the audit } \\
\text { partner responsible for the engagement has the necessary and } \\
\text { required qualifications for the audit. }\end{array}$ & 3.13 & 0.99 & 31.6 & Agree & 1 \\
\hline $\begin{array}{l}\text { X3_09 The quality of the single audit increases if the audit } \\
\text { partner responsible for the engagement has the necessary and } \\
\text { required experience for the audit. }\end{array}$ & 2.96 & 0.95 & 31.9 & Agree & 5 \\
\hline $\begin{array}{l}\text { X3_10 The quality of the single audit increases if the audit } \\
\text { partner responsible for the engagement possesses the } \\
\text { competence required for the audit. }\end{array}$ & 3.08 & 0.98 & 31.8 & Agree & 2 \\
\hline $\begin{array}{l}\text { X3_11 The quality of the single audit increases if the audit } \\
\text { partner responsible for the engagement has the necessary }\end{array}$ & 2.96 & 0.94 & 31.7 & Agree & 4 \\
\hline
\end{tabular}




\begin{tabular}{|c|c|c|c|c|c|}
\hline$\frac{\frac{\mathscr{O}}{2}}{\frac{. \pi}{\pi}}$ & $\stackrel{\Xi}{\sum_{\Sigma}^{\varpi}}$ & 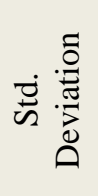 & 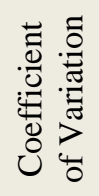 & 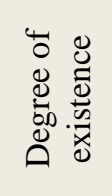 & $\underset{\widetilde{\Xi}}{\check{E}}$ \\
\hline \multicolumn{6}{|l|}{$\begin{array}{l}\text { number of years of supervision of the audit work for the client } \\
\text { under audit. }\end{array}$} \\
\hline $\begin{array}{l}\text { X3_12 The quality of the single audit increases if the audit } \\
\text { partner in charge of the engagement has many audited clients. }\end{array}$ & 3.01 & 0.94 & 31.3 & Agree & 3 \\
\hline $\begin{array}{l}\text { X3_13 The quality of the single audit increases if there is } \\
\text { appropriate level of competence, expertise and qualifications of } \\
\text { the audit managers and other members of the audit team } \\
\text { responsible for the audit. }\end{array}$ & 2.88 & 0.94 & 32.8 & Agree & 6 \\
\hline $\begin{array}{l}\text { X3_14 The quality of the single audit increases if there are } \\
\text { industrial specialization of the activities and practices of the } \\
\text { client under audit. }\end{array}$ & 2.85 & 0.97 & 34.0 & Agree & 7 \\
\hline X3_B (Overall mean) & 2.98 & 0.79 & 26.4 & Agree & \\
\hline
\end{tabular}

\section{Wilcoxon Signed Rank Test}

Table 11 revealed a statistically significant differences between the level of experience of the joint audit and the single audit since $\mathrm{z}=-5.277, \mathrm{p}<.001$, with a small effect size $(\mathrm{r}=.29)$. Such differences are in favor of joint audit engagements with level of experience since the median score is $M d=3.29$ while the median score of single audits with level of experience is $M d=3.00$. Therefore, we accept $\mathrm{H} 3$.

Table 11 Wilcoxon signed ranks test of audit quality with differences in the level of experience of the auditors involved in the joint compared to single audit.

\begin{tabular}{|l|c|c|c|c|}
\hline \multicolumn{1}{|c|}{ Variables } & Median & Z & Sig. & Effect size \\
\hline $\begin{array}{l}\text { X3_A Differences in the level of competence of joint auditor } \\
\text { involved in the audit work }\end{array}$ & 3.29 & -5.277 & 0.000 & 0.285 \\
\cline { 1 - 3 } X3_B The case of single competent audit firm & 3.00 & & \\
\hline
\end{tabular}

\subsection{Descriptive and Inferential Statistical Tests for $\mathbf{H 4}$}

Table 12 shows that auditors agreed that the quality of audit increases in listed companies compared with unlisted company with overall mean of 2.93. This is also confirmed if the listed companies are audited by one of the Big 4. Similarly, table 12 also shows that auditors agreed that the quality of audit in non-listed companies increases whether they are executed by one or more audit firms, including one of the Big 4 or if there are differences in the level of experience and qualifications of the partners responsible for the engagement. 
Table 12: Descriptive analysis for the quality of audit work in listed versus unlisted companies

\begin{tabular}{|c|c|c|c|c|c|}
\hline$\frac{\frac{\partial}{\partial}}{\frac{\pi}{\pi}}$ & $\stackrel{\varpi}{\varpi ँ}^{\Xi}$ & 离 & 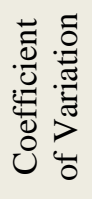 & 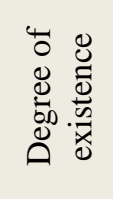 & 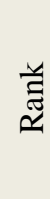 \\
\hline $\begin{array}{l}\text { Joint audit and listed versus unlisted companies } \\
\text { X4_01 The quality of the audit of listed companies increases in } \\
\text { case they are executed by one or more of the audit firms. }\end{array}$ & 2.95 & 0.95 & 32.3 & Agree & 1 \\
\hline $\begin{array}{l}\text { X4_03 The quality of the audit of listed companies increases in } \\
\text { case they are executed by one or more of the audit firms, } \\
\text { including one of the big } 4 \text {. }\end{array}$ & 2.95 & 0.95 & 32.1 & Agree & 2 \\
\hline $\begin{array}{l}\text { X4_05 The quality of the audit work of listed companies } \\
\text { increases in case they are carried out by one or more of the } \\
\text { audit firms, even if there is a disparity in the level of experience } \\
\text { and qualification of the partners. }\end{array}$ & 2.87 & 0.95 & 33.2 & Agree & 3 \\
\hline X4_A (Overall mean) & 2.93 & 0.83 & 28.3 & Agree & \\
\hline $\begin{array}{l}\text { Single audit and listed versus unlisted companies } \\
\text { X4_02 The quality of the audit of non-listed companies } \\
\text { increases in case they are executed by one or more audit firm. }\end{array}$ & 3.07 & 0.98 & 32.0 & Agree & 1 \\
\hline $\begin{array}{l}\text { X4_04 The quality of the audit of non-listed companies } \\
\text { increases in case they are executed by one or more audit firm } \\
\text { including one of the big } 4 \text { firm. }\end{array}$ & 3.00 & 0.95 & 31.6 & Agree & 2 \\
\hline
\end{tabular}

\begin{tabular}{|l|c|c|c|c|c|}
\hline $\begin{array}{l}\text { X4_06 The quality of the audit of non-listed companies } \\
\text { increases in case they are carried out by one or more audit firm, } \\
\text { even if there is a disparity in the level of experience and } \\
\text { qualification of the partners. }\end{array}$ & 2.84 & 0.97 & 34.2 & Agree & 3 \\
\hline X4_B (overall mean). & 3.09 & 0.70 & 22.6 & Agree & \\
\hline
\end{tabular}

\section{Wilcoxon Signed Rank Test}

Table 13 reveals a non-statistically significant differences between the quality of the audit in listed versus non-listed companies in joint and single audit since $\mathrm{z}$ is equal to -1.282 , with $\mathrm{p}$ equal 0.200 . So, we reject H4. A possible interpretation for such result is that the efforts, time and cost provided by auditors for listed compared to non-listed companies are the same given that there no severe penalties for violation of laws and regulations for listed compared to non-listed companies. Thus, auditors tend to provide the same quality of audit for both types of companies.

Table 13 Wilcoxon signed ranks test of differences of quality of audit in listed versus non-listed companies

\begin{tabular}{|l|c|c|c|c|}
\hline \multicolumn{1}{|c|}{ Variables } & Median & $\mathrm{Z}$ & Sig. & Effect size \\
\hline X4_A the quality of audit work in listed companies & 3.00 & & 0.20 & \\
\cline { 1 - 2 } X4_B the quality of audit work in non-listed companies & 3.00 & -1.282 & $\begin{array}{c}0 \\
0\end{array}$ & 0.069 \\
\hline
\end{tabular}




\section{5- Conclusion}

Mixed results were found in the audit literature concerning the effect of joint audit on audit quality without real comparison with a single audit engagement. The results of the current study indicate the acceptance of $\mathrm{H} 1$ confirming that joint audit does enhance the quality of the audit compared to single audit. Brainstorming among auditors in joint audit engagements result in close interconnectedness in the performance of the audit, thus achieving the required results of the audit. Also, competition among auditors motivate them to achieve accuracy and precision in their audit tasks. The independence of the auditors in joint audit would be enhanced compared to single audit due to less probability of familiarity or collusion with the client as the work among the joint auditors can always be rotated. Finally, joint audit engagements allow cross review of each of the joint auditors' work. In addition, the results of testing $\mathrm{H} 2$ confirmed the positive effects of the Big 4 in a joint audit engagement and the audit quality. Big 4 audit firms have wider client base which give them opportunity to acquire greater knowledge and expertise in addition to highly technical and financial support provided by their international networks worldwide. Also, auditors working in Big 4 have more peers to consult with and hence have a better local support network. Big 4 firms have continuous training programs, standardized audit programs and firm-wide knowledge sharing practice supported by information technology. Moreover, the results of testing $\mathrm{H} 3$ reveal no variation in the audit quality when there is difference in the level of competence and experience possessed by the audit partners (and the audit team) in the audit firms participating in the joint audit compared to a single audit except when there are discrepancies in the size of the audit client. On the other hand, $\mathrm{H} 4$ was rejected as the statistical tests showed no variation in the audit quality in a joint audit compared with a single audit for listed companies compared to non-listed. This is due to the discrepancies in the joint audit partners' level of experience and professional qualifications relevant to the audit engagements.

The current research provides several important contributions to the auditing literature. First, the research is among the first to study the impact of joint audit compared with single audit on the audit quality in an emerging economy such as Egypt. Second, the research also empirically identified shortcomings with those two types of the audit especially in relation to the effect of differences of the level of competence and experience of the partners and the audit team on audit quality. Third, the results highlighted the importance and necessity to perform joint audit engagements involving one of the Big 4 audit firms with one audit partner possessing industry specialization in the audit assignment. Such findings have implications on the audit literature related to the significance of the level of competence and experience of the partners and audit teams on audit quality whatever the type and size of the audit firm employed. Fourth, the study provides valuable insights and recommendations for audit firms, oversight boards and professional bodies to encourage the use of joint audit versus single audit for business enterprises to enhance audit quality. The research recommends that the members of the single or the joint audit firms obtain relevant professional and specialized training courses in the client's industry. The research also provides a deeper analysis from practitioners in the audit field of how different audit firms 
with different levels of competence and experience deal with the challenges they face while conducting a joint audit to achieve high quality audit.

The research study has some limitations. The research methodology relied on data collected from only five audit firms including two of the Big 4 taken into consideration the difficulty to communicate with partners, managers and seniors in audit firms due to their usual busy schedules to perform their diversified audit tasks. Also, limited number of interviews with academics and audit partners were undertaken given they were from both Big 4 and non-Big 4 audit firms. Culture of an audit may form part of the research construct. Future research should look at testing whether the culture of an organization may influence the presence of social loafing which in turn lead to ineffective joint audits. Also, an assumption has been made that joint audits provide a fair representation of inter organizational collaboration. Future research will have to challenge this assumption. A suggestion would be to test this using empirical research. Some research papers also found that when market uncertainty is high (i.e., presence of Covid-19), the quality of collaboration is improved and the joint audit quality is better (Hallen at all., 2014). This is because the transactions would be more complex, and each audit already has a unique value proposition they are bringing to the table. Further research is needed to empirically investigate this aspect. Future research should also look at testing the impact of joint audits in an IT environment on enhancing the professional judgement of the auditors and its implications on the detection of material misstatements. Finally, future research should explore the impact of corporate governance mechanisms on the effectiveness of the joint audits.

\section{References}

- Abdel Razik, D. (2017). The determinants of Audit fees and Report Lag: A comparative study of Egypt and UK. available at: http://hdl.handle.net/10026.1/9510. pp. 115-125.

- Alanezi, F., Alfaraih, M., Alrashaird, E., and Albolushi, S. (2012). Dual joint auditors and the level of compliance with international financial reporting standards (IFRS-Required disclosure). The case of financial institutions in Kuwait. Journal of Economic and Administrative Sciences, 28(2), 109-129.

- Alfaraih M., and Alanezi. F. (2012). The Effectiveness of Joint auditor requirements in promoting corporate disclosure quality. Arab Journal of Administrative Sciences, 19(2), 245-270.

- Al-Khaddash, H., Al Nawas, R., Ramadan, A. (2013). Factors affecting the quality of Auditing: The Case of Jordanian Commercial Banks. International Journal of Business and Social Science, 4 (11), 205-210.

-Alsadoun, N., and Aljabr, Y. (2014). Joint Audit and Cost of Equity Capital: Evidence from Saudi Arabic. available at: www.fac.ksu.cdu.sa/

- Andre, P., Broye, G., Pong. C, and Schatt, A. (2016). Are joint Audits Associated with Higher Audit Fees? European Accounting Review, 25, 245-274.

- Arens, A. A., Elder. R. J., Beasley. M.S., Hegazy, M. (2013). Auditing and Assurance Services. Pearson Education Limited. 
- Audousset-Coulier, S. (2012). Two big or not "two Big"? The consequences of appointing two big 4 auditors on audit pricing in a joint audit setting. available at: www.ssrn.com. 2- 38.

- Baldauf, J., and Steckel, R. (2012). Joint Audit and Accuracy of the Auditor's Report: An Empirical Study. International Journal of Economic, Sciences and Applied Research, 5 (2), 7-42.

- Beck., M. J. Gunn., J. L. and Hallman N. (2019). The geographic decentralization of audit firms and audit quality, Journal of Accounting and Economics, https://doi.org/10.1016/j.jacceco. 2019. 101234

- Behn, B., J. Choi, and T. Kang (2008). Audit quality and properties of analyst earnings forecasts. The Accounting Review, 83 (3), 327-349.

- Benali, A. (2013). The Shareholders Confidence and Effectiveness of the Joint Auditors: Empirical Validation in the French Context. International Journal of Business \& Management, 8 (11), 76-84.

- Bills, K. L., Jeter. D.C., \& Stein, S.E. (2013). Auditor Industry Specialization and Evidence of Cost Efficiencies in Homogenous Industries. Available at: SSRN 2321741.

- Carcello, J.V., and Nagy. A.L. (2004). Client size. auditor specialization and fraudulent Financial

Reporting. Managerial Auditing Journal. 10.1108/02686900410537775

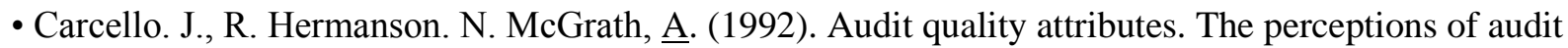
partners preparers and financial statement users. Auditing: A Journal of Practice \& Theory. 11, 1-15.

- Chihi, H., and Mhirsi, N. (2013). Joint audits and audit quality: A matter of size and/or seniority. International Symposium on Audit Research, Available at: http://www.isarhg.org/Donloads/ ISAR_FinalProgram_29 May2013.pdf

- De Angelo. L., 1981. Auditor Size and audit quality. Journal of Accounting and Economic, 3,183-199.

- Deng, M., Lu, T., Simunic, D., and Ye, M. (2014). Do Joint Audits Improve or Impair Audit Quality? Journal of Accounting Research, 52(5), 1029-1060.

- Dopuch, N., and Simunic. D. A. (1980). The nature of competition in the auditing profession: descriptive and normative view. In Regulation and the Accounting Profession, editors J. Buckley and F. Weston, 7794: Belmont, California: J. F. Lifetime Learning Publications.

- European Commission (2010). Green Paper: Audit policy: Lessons from the crisis Brussels: European Commission.

-Ferguson, A., Francis, J. R., and Stokes. D. J. (2003). The Effects of Firm-Wide and Office-Level Industry Expertise on Audit Pricing. The Accounting Review, 78 (2), pp. 429-448

- Francis, J. R., and Michas, P. N. (2013). The contagion effect of low-Quality audits. The Accounting Review, 88(2), 521-552. 
- Francis, J.R., and Yu. M. (2009). Big 4 office size and audit quality. The Accounting Review, 84 (5), 15211552.

- Francis, J.R., Richard C., and Vanstraelen, A. (2009). Assessing France's joint audit requirement are two heads better than one? Auditing. A Journal of Practice \& Theory. 28 (2), 35-63.

- Hay, D. C., Knechel, W.R., and Wong, N. (2006). Audit Fees: A Meta-analysis of the Effect of Supply and Demand Attributes. Contemporary Accounting Research, 23, 141-191

- Hegazy, M., Al-Sabagh, A., and Hamdy, R. (2015). The effects of Audit Firm Specialization on Earnings Management and Quality of Audit work. Journal of Accounting and Finance, 15 (4), 143-164.

- Holm, C., and Thinggaard, F. (2010). Joint audits-benefit or burden? Working Paper. available at: www.ssrn.com

- Holm, C., and Thinggaard, F. (2016). Paying for Joint or Single Audits? The importance of Auditor Pairings and Differences in Technology Efficiency. International Journal of Auditing. 20 (1), 1-16.

- Holm, C., and Thinggaard, F. (2018). From joint to single audits - Audit Quality differences and Auditor pairings. Accounting and Business Research, 48 (3). 321-344.

- Hossain, S., Yazawa, K., \& Monroe, G. (2017). The relationship between Audit Team composition Audit Fees, and Quality. Auditing: A Journal of practice \& Theory. 36 (3), 115-135.

- Ittonen, K., and Tronnes, P. (2015). Benefits and costs of appointing joint audit engagement partners. Auditing: A Journal of Practice and Theory, 34 (3), 23-46.

- Khurana, I.K., and Ruman, K. K. (2004). Litigation risk and the financial reporting credibility of big 4 versus non-Big 4 audits; Evidence from Anglo-American counties. The Accounting Review, 79 (2), 473495.

- Lesage, C., Ratzinger, Sakel, N., \& Kettunen, J. (2012). Struggle over joint audit: on behalf of public interest? Working paper available at: www.ssrn.com

- Lesage, C., Ratzinger-Sakel. N.V.S. and Kettunen, J. (2017). 'Consequences of the Abandonment of Mandatory Joint Audit: An Empirical Study of Audit Costs and Audit Quality Effects'. European Accounting Review. 26, 311-339.

- Lobo, G., Paugam, I., Zhang, I., and Casta, J. (2013). Effect of Joint Auditor Pair on Conservatism: Evidence from Impairment Tests. Comptabilité sans Frontieres. Available at: https://halshs.archivesouvertes.fr/hal-00993007/document

- Marmousez., S. (2009). The choice of joint-auditors and earnings quality: Evidence from French listed companies. Canadian Academic Accounting Association. Annual Conference. Montreal.

- Mazars. (2010). Contribution to the consultation on the Green Paper "Audit policy: Lessons from the crisis". Mazars publication. 
- Paugam, L. and Ramond. O. (2015). Effect of impairment-testing disclosures on cost of equity Capital. Journal of Business Finance and Accounting 42(5-6), 515-54.

- Paugam, L., and Casta, J. (2012). Joint Audit, Game Theory, and Impairment-Testing Disclosures working paper, available at: http://halshs.archives-ouvertes.fr/halshs-00671613/document

Philippe L., and Simunic, D. A. (2011). Auditor Size and Audit Quality Revisited: The Importance of Audit Technology. Working paper available at: www.ssrn.com

-Ratzinger-Sakel, N., Audousset-Coulier, S., Kettunen, J., and Lesage. C. (2012). What do we know about joint audit? ICAS Report. Edinburgh: ICAS.

- Relvas, G., and Pais, C. (2015). The cost of Debt. Dimension of the auditor and Joint Auditors: The case of the Largest European Companies. working paper, available at: http://www.aecal.org/pub/on line/ comunicaciones-Xviencuentroaeca/cd/69a.pdf

-Saunders, M., Lewis, P., and Thornhill, A. (2007). Research Methods for Business Students. Prentice Hall International.

-Velte, P., and Azibi, J. (2015). Are Joint Auditees a Proper Instrument for increased Audit Quality? British Journal of Applied Science and Technology, 7(6), 529-551.

- Zahra S., and Josep Garcia B. (2019). Audit quality, joint or single audit regimes: An empirical study of the consequence of Joint audit abandonment in Denmark. Available at: http://accid.org.

- Zerni, M., Elina, H., Jarvinen, T., and Niemi, L. (2012). Do joints audits improve audit quality? Evidence from voluntary joint audits. European Accounting Review, 21(4), 731-765. 
Appendix: Test of normality

\begin{tabular}{|c|c|c|c|c|c|c|}
\hline \multicolumn{7}{|c|}{ Tests of Normality } \\
\hline & \multicolumn{3}{|c|}{ Kolmogorov-Smirnov ${ }^{\mathrm{a}}$} & \multicolumn{3}{|c|}{ Shapiro-Wilk } \\
\hline & Statistic & df & Sig. & Statistic & df & Sig. \\
\hline X1_A Joint audit engagement & .080 & 172 & .009 & .974 & 172 & .003 \\
\hline X1_B Single audit engagement & .110 & 172 & .000 & .963 & 172 & .000 \\
\hline X2_A Joint audit with one of the big 4 audit firm & .115 & 172 & .000 & .953 & 172 & .000 \\
\hline X2_B Single audit conducted by one of the big 4 . & .073 & 172 & .027 & .976 & 172 & .005 \\
\hline $\begin{array}{l}\text { X3_A Joint audit with qualified and level of } \\
\text { experience }\end{array}$ & .089 & 172 & .002 & .980 & 172 & .015 \\
\hline X3_B Single qualified and experienced audit firm. & .095 & 172 & .001 & .968 & 172 & .000 \\
\hline $\begin{array}{l}\text { X4_A the quality of audit work in companies listed } \\
\text { on the Egyptian Stock Ex-change }\end{array}$ & .147 & 172 & .000 & .944 & 172 & .000 \\
\hline $\begin{array}{l}\text { X4_B the quality of audit work in companies non- } \\
\text { listed on the Egyptian Stock Ex-change }\end{array}$ & .131 & 172 & .000 & .950 & 172 & .000 \\
\hline $\begin{array}{l}\text { X5_A The joint audit from more than one office } \\
\text { with specialized experience in the industry. }\end{array}$ & .103 & 172 & .000 & .967 & 172 & .000 \\
\hline X5_B the audit work by a single comptroller's office. & .137 & 172 & .000 & .943 & 172 & .000 \\
\hline
\end{tabular}

a. Lilliefors Significance Correction 